Covered in: Web of Sciences (WOS); EBSCO; ERIH+; Google Scholar; Index Copernicus; Ideas RePeC; Econpapers; Socionet; CEEOL; Ulrich ProQuest; Cabell, Journalseek; Scipio; Philpapers; SHERPA/RoMEO repositories; KVK; WorldCat; CrossRef; CrossCheck

2019, Volume 11, Issue 3, pages: 290-307 | doi:10.18662/rrem/152

\title{
Organizational and Pedagogical Conditions of Preschool Educational Institution and Family Partnership in the Republic of Poland
}

\section{Liudmyla TYMCHUK', Inna PEREPELIUK², Marianna MARUSYNETS', Khrystyna MYKYTEIHCUK ${ }^{4}$}

${ }^{1}$ Yuriy Fedkovych Chernivtsi National University, Pedagogical, Psychology and Social Work Faculty, Chernivtsi, Ukraine, 1.tymchuk@,chnu.edu.ua

${ }^{2}$ Yuriy Fedkovych Chernivtsi National University, Pedagogical, Psychology and Social Work Faculty, Chernivtsi, Ukraine, i.perepeliuk@,chnu.edu.ua

\section{${ }^{3}$ Ivan Ziaziun Institute of Pedagogical and Adult Education of the NAES of Ukraine, Foreign Pedagogical Systems and Adult Education Department, Kyiv, Ukraine, marusynetsm@ukr.net}

${ }^{4}$ Yuriy Fedkovych Chernivtsi National University,Pedagogical, Psychology and Social Work Faculty, Chernivtsi, Ukraine, k.mykvteichuk@.chnu.edu.ua
Abstract: The theoretical ideas are systematized and the experience of partnership of the preschool institution and the family in bringing up children in the Republic of Poland is generalized. On the basis of normative and legal documents the priority of partnership interaction between preschool institutions and the family in the concept of the modern national educational policy of the Republic of Poland was argued. The methodological principles of partnership as a kind of interrelations between teachers and parents are substantiated, which consists of the common purpose and actions, equality of rights and responsibilities to children, their education and personal formation. The components of the partnership (intellectual, emotional, volitional, behavioral, valuable), principles of its realization (mutual trust, recognition of rights and competence, positive motivation, loyalty, commonality of actions, information exchange, activity) are characterized. The technique of effective communication and understanding between educational partners is presented; the purpose and content of the partnership of modern preschool institutions and family in the Republic of Poland are specified (parents' integration in the pedagogical process for the child's support). The organizational forms of interaction between teachers and parents are classified on the basis of different criteria; there is systematized the competence of teachers and the resource of parents as partners in the upbringing of the child.

The prospects of creative use of Polish experience in the theory and practice of preschool education in Ukraine are outlined.

Keywords: pre-school education; partnership; cooperation; interaction; partnership of the preschool institution and parents in the child's upbringing.

How to cite: Tymchuk, L., Perepeliuk, I., Marusynets, M., \& Mykyteihcuk, K. (2019). Organizational and Pedagogical Conditions of Preschool Educational Institution and Family Partnership in the Republic of Poland. Revista Romaneasca pentru Educatie Multidimensionala, 11(3), 290-307.

doi:10.18662/rrem/152 



\section{Introduction}

The key component of the New Ukrainian School concept is the partnership pedagogy, based on which is communication, interaction and collaboration between teachers, children and parents, united by common goals and ambitions and are voluntary and interested associates, equal participants in the educational process, responsible for the result.

Nowadays the organization of educational activities on the partnership basis is recognized as the condition and criterion for the effectiveness of pre-school education that is a mandatory primary link of the continuous education system in Ukraine.

The educational influences unity of the family and the institution of preschool education in the Law of Ukraine "On Preschool Education" was fixed as one of its main principles. The state guarantees the family "comprehensive assistance in the development of child's upbringing and education" (The Law of Ukraine "On Preschool Education", 2005, Art. 3), and the family is obliged to "promote the acquisition of education by the child in preschool and other educational institutions or provide pre-school education in the family" (The Law of Ukraine "On Preschool Education", 2005, Art. 8).

Working with parents is a traditional component of preschool education. However, today this theme has got a new twist. The modern family develops in a qualitatively new contradictory social situation. On the one hand, processes leading to the family problems aggravation become common. First of all, this is because of a decline in the living standards of most families, the economic problems solution, and, sometimes, physical survival, which has aggravated the social tendency of many parents to remove them from the decision of the education and personal development issues of the child. On the other hand, society is turning to family problems, comprehensive targeted programs are being developed and implemented to strengthen and increase its significance in the education of children. Parents themselves show an increasing desire not to passively observe the process of raising their child in the preschool education institution, but to be an active participant. The paradigm of relations between educators, as representatives of the educational system, and parents, as representatives of their own children and defenders of their rights, is changing.

In this context, updating the strategy and tactics of interaction between teachers and parents, changing its vectors and emphases in the direction of partnership interaction, expanding the range of vital problems, 
providing cooperation for greater sincerity, openness, constructiveness, and exemption from excessive formalism are relevant in this context.

An important source for the formation of a modern concept of preschool education that introduces changes in the establishment of pedagogical relationships between preschool institutions and the family can be an example of foreign experience, in particular, Poland, where in the 90's of the XX century active paternity movement intensified. One of the main principles of the Polish education reform was the organization of coresponsibility for the training of all its participants and interested parties i.e. educators, children and parents. Due to changes, parents partially take on the responsibility to create opportunities for influencing the conditions and quality of a pre-school institution, resulting in the integration of both environments activities.

\section{Review of literature}

Participation of parents in the educational process of the pre-school institution is intensified in the problems of discussions in Polish pedagogical circles, scientific and journalistic literature, and in fundamental researches by Bulera and Wojciechowska (2002), I. Dziezgowska (2001), M. Lobocki (2007), M. Mendel (1988), Y. Radziewicz (1992), E. Trempala (1976) and others. The general context of the partnerhip development of the preschool institution and family in the theory and practice of preschool education is presented in the writings of such leading Polish scientists as A. Kaminski (1974), S. Nowak (1985), R. Pachocinski (2000) etc.

The experience of the Polish reform in education is considered a convincing example of achievements as a result of systemic changes that were oriented towards the program and organizational hospitability of teachers and parents as partners in the child's upbringing. Against the backdrop of geographical and cultural proximity, this experience, we believe, has an objective value for Ukrainian pre-school education.

The methodological and methodical principles of the preschool institution and family partnership in the Republic of Poland are still insufficiently comprehended in the modern scientific literature. An overview of the Ukrainian scholars researches on the problem we have raised, as well as the organization, conceptual foundations and trends of the development of preschool education in the Republic of Poland in general suggests that it is promising for further study. 
The aforementioned context of the modern theory and practice of preschool education of Ukraine and the Republic of Poland, a number of contradictions are evident that prove the relevance of the issue between:

- an increase in the requirements of society to the parents' competence in the new socio-economic conditions and the real level of their readiness to exercise their rights and duties in relation to the child's education and upbringing;

- accumulated Polish experience in working with parents of preschool children and inadequate creative studying the ways of its implementation in the modern conditions of the Ukrainian preschool for the effective partnership interaction organization;

- the expediency of establishing the interaction between the institution of preschool education and the family on the basis of partnership and the inadequate theoretical foundations and practical experience of its organization in the education system of Ukraine.

Consequently, the social significance of the outlined problem, its novelty for the Ukrainian pedagogical science and the necessity to solve objective contradictions, actualize the subject of this publication.

\section{Design and methods}

\subsection{The aim of article}

The aim of this paper is to uncover the organizational and pedagogical conditions of the partnership of the preschool institution and family in the Republic of Poland and to identify the prospects of creative implementation of the ideas of positive experience in the Ukrainian preschool education.

\subsection{Methods}

In the process of scientific research, were used such methods as:

- general science - analysis, synthesis, systematization, classification for generalization of information from scientific and pedagogical sources, which presents the problems of the institution interaction of preschool education with parents; problem-targeted analysis of legislative and normative acts, materials of the periodical press and the Internet on a given problem in order to monitor the dynamics of changes in the legislative and socio-cultural spheres that determine the cooperation of pre-school institutions with parents;

- historic - historic-comparative, chronological, typological, logicalhistorical and retrospective for the analysis of the partnership process 
between the pre-school institution and the parents of children in dynamics, changes and timeliness;

- comparative and contrastive - prognosis and interpretation of the analysis results with the aim of studying the experience in partnership of the preschool institution with parents in domestic and foreign practice and possibilities of its creative use in the modern education of Ukraine;

- empirical - diagnostic (questioning, conversation, studying documentation), observational (observing the work of kindergartens in the cities of Kielce, Radom, Krakow, Tarnobzheg).

\section{The results of the research}

In order to find out the essence of the disturbed problem, its retrospective analysis in Polish pedagogical theory and practice has been carried out firstly. Based on the results of the analysis of the source base, it was discovered that since the 17th century, Polish authors considered the issue raised in various aspects: the duties of parents regarding the education of children outside the family, in the period of their studies in of institutional education establishments; a characterization of a teacher as an assistant to parents in bringing up children; cooperation with parents as a necessary condition for the professional ethics of the teacher (Jakubiak, 2014). In spite of the theoretical recognition in the Polish pedagogical thought of the importance and positive influence of the teachers and parents interaction on the children's education, in educational practice until the second half of the nineteenth century the problem has not yet gained significant meaning: it was a question of cooperation in education, which was limited by parents' education about the children's training; concerning parents their provision and support of the material conditions of the child's education in educational institutions.

In the context of civilizational transformations and changes in the field of social relations, against the backdrop of democratization processes, the school functions expansion, socially motivated and evident the need for cooperation between teachers and parents. At the turn of the XIXXX centuries the literature postulates the idea of synthesis and harmonization of the influence of the main educational factors such as state, schools, churches and families, broad social groups (Joteyko, 1927).

In the then Polish pedagogy, a number of concepts were formulated on the functioning of the school, firstly, as a harmonious team of children, teachers and parents, and secondly, as structures covering all of human life and working conditions, reflects the connection of the school with life and 
society. In the context of the above, we emphasize the originality of the proposal by Ya. Joteyko (1927) to create a broad educational environment for educational institutions in the form of parental groups that united them with teachers and envisaged an increase in the pedagogical culture of the environment in which the child is raised (Joteyko, 1927).

The theoretical achievements of the Polish social pedagogy of the 1920s-1930s are worthy of attention. They are in the works of Ya. Bystron (1930), I. Grzegorzewska (1935), and others. The concept of the educational environment in which the interaction of the educational institution with the family is recognized as a fundamental factor in social life and the formation of educational processes is presented (Bystroń, 1930; Radlińska, 1961). The importance of this problem was foreseen by the Polish teachers in optimizing the child's ability to understand the environment and the conditions of his/her life, supporting the continuity of the child's development, drawing on the personal experience acquired at school and at home; for educators, it is important to parent's care for the child, and for parents there exists professional explanation by the teachers of the conditions for the child's development, information about various events and conflicts that occur in the environment of the child, counseling.

It should be noted that these issues became of particular importance in the conditions of the dominant idea of family rebirth and the call of the Republic of Poland to create a strong nation by strong families. Educational policy and pedagogical thought unanimously and unambiguously recognized the equality of the influence of social institutions on the child's upbringing, defending the need for their harmonious unity. Indicative in this context, consider the credo of the then public activist I. Pannenkowa (1931), who argued that revenge for the child is a lack of harmony between the state, the church, school, society and family (Pannenkowa, 1931).

During the study, we have investigated and substantiated the fundamental variability in the interpretation of the issues raised since the Second World War: since 1949, under the influence of total indoctrination and politicization and the construction of the socialist Republic of Poland, parents were displaced to secondary positions in the child's upbringing. According to the analysis results of publications in periodicals until 1956, it was found that the main influence on the education of children and young people was given to the school, while the family performed auxiliary, mainly physical functions.

It is proved that in practice the complex forms of work with parents (universities for parents), which focused on the provision of methodological assistance in the children education (Foks, 1956), became especially 
common. However, the real political structure in the Republic of Poland used them first and foremost as an instrument of ideological and political influence on each family. As a result of this, the relationship between different institutions for the education of children acquired formal content. Constant politicization of the educational institutions activity, through the filling of the official school life with ideological and political problems, the recognition of educational institutions as central to the organization of education of the child made it impossible to cooperate properly with families in general.

The revival of school and family relations traditions was intensified in the late 1980s, with the launch of a long-term process of democratization and humanization in all spheres of life in the Republic of Poland. As for the functioning of the new school, two concepts were formed. The first one is the managerial that is intended to address the issues of the autonomy of the educational institution, and the second one is defined priorities in cooperation and interaction on the partner basis of educational institutions with the families of pupils.

The partnership of the preschool and family in the Republic of Poland is currently regulated by a number of normative and legal documents, which specify the rights and responsibilities of parents concerning the education of children, which are guaranteed by international instruments (European Convention on Human Rights and the fundamental freedoms of 1950, the UN Convention on the Rights of the Child of 1991, the European Charter of Rights and Obligations to parents in 1992). The clear position regarding the legal provision of a partnership between the educational institution and the family is documented in the national legislation of the Republic of Poland ("Report on the Status and Directions of Education Development ...", September 7, 1991, the Constitution of the Republic of Poland in 1997, the Law on the Status of the Teacher and the Law on Juvenile Delinquency" of July 25, 2008, the Education Act of December 14, 2016.)

The content of the above-mentioned documents highlights the essence of the officially fixed status of the three-sidedness of an educational institution, which teachers, parents and children are recognized as equal subjects of the educational process. On their basis, we will outline the scope of involving parents in the education and education of a child in an educational institution. So, in the field of parenting and caring for parents, the following responsibilities are assigned:

- conscious choice of institution that responds to children and parents in terms of education, educational program; 
- familiarization with the educational program of the school, active participation in its creation;

- conversation with the teacher about the children, their difficulties and abilities;

- in the case of educational difficulties, notification of a problem and request for help from a tutor, a teacher, a school counselor, a school psychologist;

- participation in parents' council or pedagogical council;

- active assistance to teachers in the preparation of trips, holidays, school newspapers and other events that influence the formation of a positive attitude of the child to education,

- participation in courses, trainings and seminars offered for parents by educational institution;

- explanation of the child's absence in an educational institution (in the absence of a child more than 5 days);

- visits to an educational institution at the request of a teacher or manager, child,

- reimbursement of expenses for restoring equipment destroyed by a

- personal involvement in the life of the institution,

- involvement as a partner in teaching children in school, pre-school.

In the field of education parents are obliged:

- to provide conditions for the obligation to attend a preschool institution (from 5 years old) and a school,

- to provide the child with conditions for study at home,

- to familiarize with the curriculum, according to which classes will be held at a preschool institution or school,

- to maintain contact with teachers and monitor the results of the development and training of the child,

- to motivate the child to study and participate in extracurricular activities, clubs, circles,

- to support the child in the difficulty of studying, applying to the teacher with a request for additional compensatory classes or, if possible, helping the child at home,

- to inform the teacher that the child is experiencing certain difficulties, etc.

Thus, legal grounds were created and mechanisms for realization of parental rights and duties on the education of the child were created; parents were able to become co-founders of kindergartens and schools; to participate in the enrollment of children in an educational institution with 
the right to choose its location, type or form of ownership (state, private, public).

According to the analysis results of normative legal acts, we conclude that modern Polish education not only declares the high level of participation of parents in the educational institutions activities, but also their rights and responsibilities for the solution of virtually all aspects of the education of their child, as well as the establishment of clear legal mechanisms for the activities coordination with educators as equivalent partners.

On the basis of the works of Polish teachers Bulera and Wojciechowska (2002), I. Dzierzgowska and Nawrot (2001), G. Kwiatkowska (1997), M. Lobocki (2007), M. Mendel (1998), V. Okon (2004), Y. Radziewicz (1992), E. Trempala (1976) we have disclosed the essence of the partnership and clarified the content of the coherent concepts of "integration", "cooperation", "collaboration".

In the general sense of "partnership" in Polish literature is presented as a kind of interconnection between individuals or their groups, which is based on the common purpose and actions and is based on the principles of equality, loyalty, mutual responsibility and assistance (Okon, 2004). In the pedagogical context, the partnership is based on the bilateralism educational support, which is based on the fact that each participant can be a provider and recipient of the educational assistance according to his/her needs and opportunities (Kujawiński, 1990).

The teachers and parents interaction in Polish pedagogy is identified as a partnership in the presence of the following characteristics: 1) combines at least two persons; 2) relies on acceptance (acceptance), mutual trust and interpersonal support; 3) participants unite the commonality of values and goals; 4) benevolence, participants courtesy, their mutual assistance in different situations of life (Radziewicz, 1992).

Polish authors acknowledge the following principles, which are fundamental for the implementation of the preschool institution with the family partnership: mutual trust; mutual recognition of rights and competences; positive motivation, mutual loyalty; joint action (integration); exchange of information, activity and systematicity (Maszke, 2002).

For relations between educational partners (teachers and parents), scientists consider the inherent number of components, namely: 1) intellectual (understand the need and the necessity to commit adequate actions to realize a single definite goal), 2) emotional (show one another sympathy, trust, goodwill, ability to come to a mutual understanding), 3) volitional (seek voluntary cooperation for the benefit of children, to be loyal to one another, responsible), 4) behavioral (culture of partner behavior); 5) 
axiological (commonality of values and value orientations) (Kuc \& Wlazlo, 1990).

In the process of cooperation of a pre-school institution with parents, for Polish teachers it is important to have an effective communication and understanding between educational partners. In the professional literature it is distinguished several of their varieties: acceptance (acceptance) and avoidance of negative attitude; "Attentive listening"; rehash; "Questioning"; the statement "I-you" in a situation of confrontation (Mendel, 1998).

To implement the ideas of partnership, it is important to establish interpersonal relationships between partners in the field of pre-school education. Mostly, Polish researchers interpret such relationships as genuine (authentic) partnerships among all participants in education. That is, teachers, parents, children are three equally important educational subjects, when each of them performs clearly defined tasks (Putkiewicz, 2002).

The usefulness of the preschool institution with the parents cooperation, as well as its interpretation as a guarantee of success in all pedagogical endeavors, is argued. According to the works of B. Pawlak (2003), A. Kamiński (1974), A. Radziwill (1975), M. Rościszewska-Woźniak (1998), E. Trempala (1976), Kh. Filipczuk (1988), a number of evolutionary processes were traced in the interpretation of the essence of the partnership. In the publications of the late 60's of the XX century, the cooperation of the educational institution and parents aimed primarily at improving the effectiveness of educational influences on the child, respectively, parents were obliged to support the activities of teachers. Since the second half of the 1970s, the educational establishment has already been positioned as an institution that directs and parenting educational activities, leaving them the right to participate in the formulation and implementation of educational tasks. Such a division of roles in practice led to the passivity of many parents, cultivating a sense of relief from responsibility for the results of education and children's training, since the priority of the joint activity was the purpose and objectives of the educational institution, and not the initiatives and problems of parents that arose in the family daily life. In addition, according to A. Radziwill (1975), the attitude of educators to parents was usually distinguished by their identification with the child; communication in high tone; systematic teachings; fears of losing their authority, which in general contradicted the essence of the partnership (Radziwiłł, 1975).

At the turn of the 80's - 90's of the XX century it is revealed a certain tradition of defining goals in cooperation between educational institution and family. They were seen in the comprehensive, correct and harmonious 
development of the child, preparing his/her for independent activity and for work, for creative participation in the realization of social tasks and management of their own lives in such way that it was valuable and happy.

In the marked years scientists wrote that such a goal is extremely well-formulated in relation to the cooperation of teachers with parents, since it concerns one common for all subject of educational influences i.e. children. Considering the goals of teachers and parents, which further motivate their mutual support for the most effective realization of the specified tasks, are important. This idea can be observed in modern studies of Polish scientists. The idea of three-sidedness (teachers-parents-children), besides establishing and maintaining friendly relations between all participants in the educational process and enhancing the motivation of children to succeed in learning, also includes other goals, such as: encouraging parents to improve their own skills and abilities; creating opportunities for contacting parents of children with similar educational needs etc. (Wojcik, 2014).

As a result of the analysis of normative legal documents, scientific works and educational and methodical literature, we summarize and characterize the eight main partnership areas of a preschool institution with the family, which, according to the Polish tradition, are considered as indicators of the effectiveness of interaction: 1) informing parents about their organizational and legislative possibilities to influence on conditions of children's preschool education; 2) providing access to all spheres of life in a preschool institution for the participation of parents in the pedagogical process organization; 3) providing consent for the participation of parents in solving the tasks of functioning of the pedagogical process in the kindergarten; 4) perception of parents as allies in activities with children; 5) support of parents' readiness for cooperation; 6) the empowerment of the right to choose and joint decision with the parents of decisions on cases concerning the children's education and upbringing; 7) promoting the dynamic development of children, educators and parents in the process of their interaction; 8) confirmation of the tendency for joint responsibility for cooperation between its two subjects i.e. parents and teachers (in the face of the preschool institution administration).

The forms and methods of work that Polish teachers actively investigate in the framework of the cooperation of the preschool institution with the family cover the historical, conceptual and philosophical, scientific and theoretical and didactic and guidance aspects.

On the basis of the generalization of the theoretical approaches of Polish teachers to the substantiation of organizational and methodical tools 
for the partnership functioning of preschool institutions and the family, we have classified organizational forms of joint participation of teachers and parents in the education and upbringing of children. In their basis, there are a number of criteria, namely: functions, period of application, quantitative indicator of participants, and dominant means of communication.

According to the functions implemented in various forms of contacts with parents, we consider the following four groups: 1) the exchange of information about the child (individual daily telephone conversations with parents, contact in cases of child disease, providing parents with a detailed assessment of the quality of the child's activities for a certain time, etc.) ; 2) current information on educational activities (correspondence with parents, general meetings of the preschool, notice on the board for parents, keeping a chronicle of the children's team, a newsletter for parents and children); 3) promotion of the unification of pedagogical, children's and parent's groups (joint celebrations, trips, participation in media events, "afternoon family meetings", etc.); 4) organizational activity of the preschool institution (joint training of teachers and parents through participation in various studios, the choice of didactic means).

The quantitative indicator systematized individual, group (team, collective), general (mass) contacts and forms of cooperation with kindergarten parents. The forms are also distinguished depending on the period of their application (adaptation or prolonged stay of the child in the kindergarten) or the dominant means of communication (oral, written, online communication), etc. Sociological researches - polls and questionnaires which allow receiving information about the child, reveal wishes of parents and their expectations about work of a preschool institution are widely practiced. The parents' involvement in preschool institutions work on a voluntary basis has become widespread.

One of the necessary conditions for the implementation of partnership interaction between the functioning of teachers and parents is their readiness for this. It has been found that in Poland, despite the equal participation in the education of children, the preschool institution as a professionally organized institution is responsible for involving parents in the interaction. Although their training is not foreseen as a direct responsibility of preschool institutions in the Republic of Poland, this area of activity is paying a lot of attention, as the psychological and pedagogical awareness of parents greatly stimulates the partnership interaction.

The systematic and generalized scientific and theoretical materials on the principles and peculiarities of the preschool establishment partnership with 
Organizational and Pedagogical Conditions of Preschool Educational Institution ... Liudmyla TYMCHUK, et al.

the family in the Republic of Poland are reflected in the preschool institution and family partnership organization model that we developed (Fig. 1).

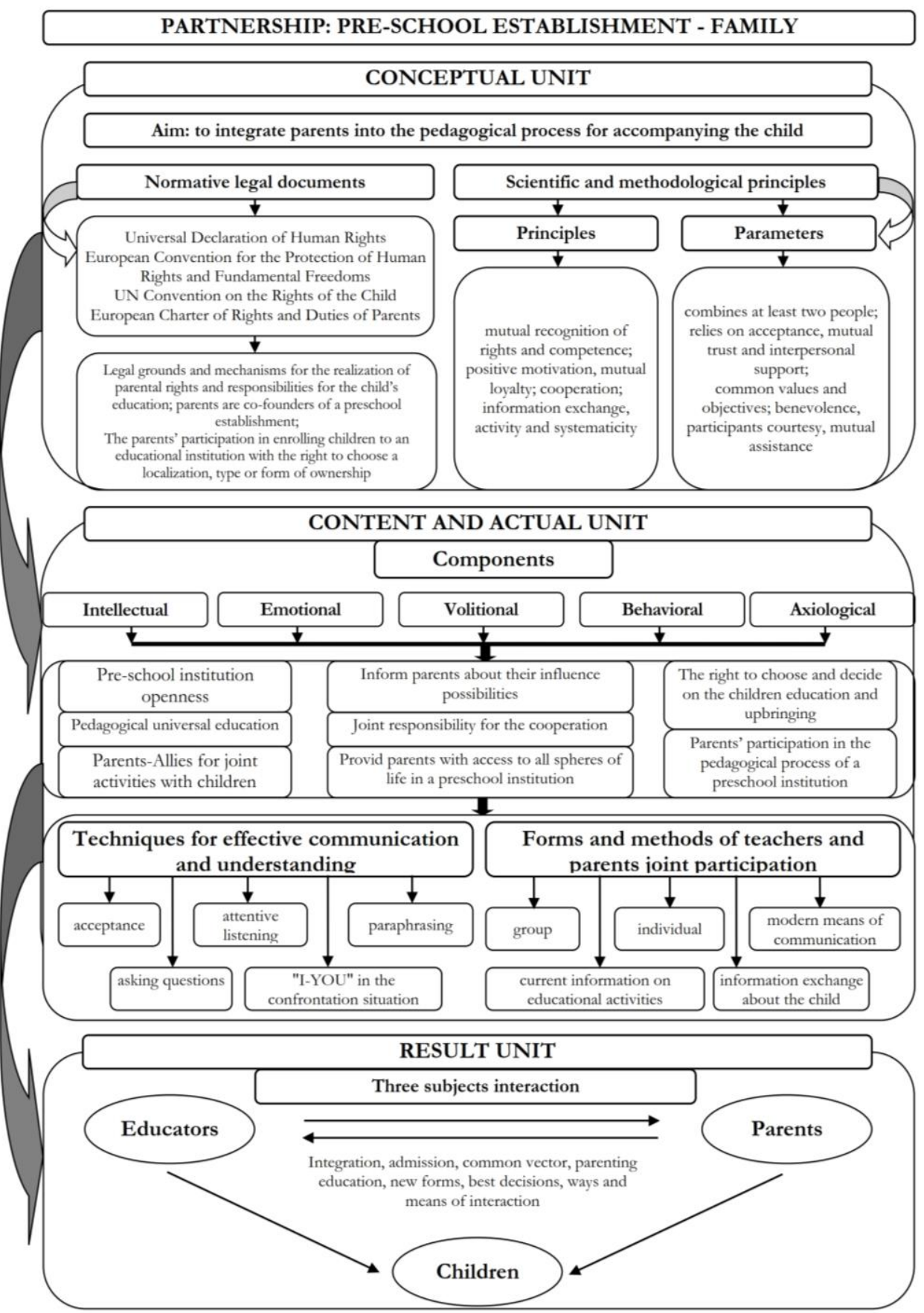


Fig. 1. The preschool establishment and family partnership organization model in the Republic of Poland

\section{Novelty of results}

According to the results of the theoretical understanding of this problem and the direct study of the work of kindergartens in certain cities of the Republic of Poland (Kielce, Radom, Krakow, Tarnobrzeg), we state the relevance of Polish experience for Ukrainian preschool education. It is advisable to consider its creative use at different levels.

The first is the involvement of parents in the management of the institution of preschool education, which aims to ensure a balance between the interests, rights and duties of teachers, parents and children as equal participants in the educational process, reflected in the collegial form of management of the institution. The administrative authority of the parents is fixed in the charter of the institution of preschool education. It not only legally ensures their partner status, but also outlines the responsibility for updating the content of education and its quality.

The second one involves the influence of parents and the responsibility for their organization of the pedagogical process in the institution of preschool education as autonomous in the choice of curricula, forms and methods of training; distribution of funds in accordance with the own budget in order to improve the teaching and methodical and material and technical base; selection of pedagogical personnel and organization of improvement of their qualification.

The third in the hierarchy of partnerships we consider the level of informing parents about the actual issues of education and upbringing of children in the form of parental collections. Their purpose is to inform the parents of the important information from the point of view of the representative of the institution (director, teacher, and psychologist). To overcome the formalism of the Ukrainian preschool in this area, we consider the use of modern technologies tested in Polish kindergartens i.e. educational Internet resources, institutions websites, parental online chats, blogs, joint cognitive classes, etc.

Perspective for use in Ukraine we also consider recognized and common in the Republic of Poland forms and methods of organizing parental universal education. It is the organization of master classes on topics offered to parents; providing information on the actual problems of children's development and creating favorable conditions for their education and upbringing; organization for parents of websites, special books rental, video films, CDs, etc. on the development of skills and abilities to ensure the 
correct education of the child in a family environment; studying the needs of young parents and ways of solving their educational problems; creation of family centers and other forms of advisory assistance; the organization of special family communities based on the specific interests or educational problems of their children; joint activities that stimulate educational and leisure activities of the family (games, contests, quizzes, evenings, excursions, joint exercises, media meetings, etc.); parent and teacher conferences and meetings; personal and written communication of teachers with parents or with representatives of the community.

\section{Conclusions}

Cooperation of educational institutions with parents as equal partners in the education and training of a growing generation has become a priority and a core of modern national educational policy in the Republic of Poland.

On the basis of theoretical ideas systematization and generalization of the preschool education experience in the Republic of Poland, we substantiated the following organizational and pedagogical conditions for the functioning of the preschool institution and the family partnership in the upbringing of children:

1) normative and legal support and recognition of the partnership interaction priority of preschool institutions with the family;

2) scientific and methodological foundations of partnership i.e. essence, principles, structural characteristics; content components; means of realization;

3) directions of parents' integration into the pedagogical process of the preschool institution, organizational forms of interaction between teachers and parents on the basis of different criteria;

4) the competence of teachers and the resource of parents as partners in the upbringing of the child.

The introduction of the content and various forms of partner interaction between teachers and parents in the practice of preschool education in the Republic of Poland reveals their potential in overcoming the barrier of parents' distrust and passivity, stimulating their activity, assisting in acquiring new experience and realizing a new role in the upbringing and education of the child: parents become full-fledged partners of the pre-school institution and participants in the pedagogical process.

\section{References}


Bulera, M., \& Wojciechowska, K. (2002). Integracja przedszkola i domu rodzinnego - potrzeba czy konieczność? [Integration of preschool and family home - is it necessaty?] In J. Jakóbowski \& A. Jakubowicz-Bryx (Eds.), Integracja w edukacji : dylematy teorii i praktyki (pp. 204-208). Bydgoszcz, Poland: Wydawnictwo Akademii Bydgoskiej.

Bystroń, J. (1930). Szkoła i społeczeństwo [School and schooling]. Lwów-Warszawa, Poland: Naukowe Towarzystwo Pedagogiczne.

Dzierzgowska, I., \& Nawrot, M. (2001). Partnerskie przedszkole [Affiliate preschool]. Zabrze, Poland: Wydawnictwo Partner.

European Parents Association. (1992). Europejska Karta Praw i Obowiązków Rodziców [The European Charter of Rights and Obligations to Parents]. Retrieved from http://sp120lodz.pl/?page $\mathrm{id}=11705$

Filipczuk, H. (1988). Driecko w placówce opiekucczo-nychowawczej [The child in a guardianship institution]. Warsaw, Poland: NK.

Foks, A. (1956). Szkola i dom [School and home]. Warsaw, Poland: Uniwersytet dla Rodziców.

Grzegorzewska, M. (1935). Wstęp, [w:] Współpraca szkoły z domem. [Cooperation of the school with parents]. In S. Lisowski (Ed.), Dosiviadczeń przeprowadzonych na terenie Szkoly Ćwiczen pray Seminarium Nauczycielskim w Wilnie, Warsaw, Poland: Nakładem "Naszej Księgarni" Spółka Akcyjna Związku Nauczycielstwa Polskiego.

Jakubiak, K. (2014). Geneza relacji i współpracy rodziny i szkoły w polskiej myśli pedagogicznej oraz praktyce edukacyjnej od XIX do połowy XX wieku. [The genesis of communication and cooperation between family and school in Polish pedagogical thought and the practice of teaching from the XIX to the mid XX century]. Edukacja Elementarna w Teorii i Praktyce : kewartalnike dla nauczycieli, 4, 27-51.

Joteyko, J. (1927). Postulaty szkoly twórczej na prawach struktur psychicznych [The postulates of the creative school on the rights of mental structures]. Warsow, Poland: Książnica - Atlas.

Kaminski, A. (1974). Funkcje pedagogiki spotecrnej [General pedagogy functions]. Warsaw, Poland: PWN.

Parliament of Poland. (1997). Konstytucja Rzeczypospolitej Polskie. [The Constitution of the Republic of Poland]. Retrieved from http://prawo.sejm.gov.pl/isap.nsf/DocDetails.xsp?id=WDU19970780483

Council of Europe. (1950). Konwencja o Ochronie Praw Człowieka i Podstawowych Wolności sporządzona w Rzymie [European Convention on Human Rights and Fundamental Freedoms]. Retrieved from bttp://prawo.sejm.gov.pl/isap.nsf/DocDetails.xsp?id=WDU19930610284 
Organizational and Pedagogical Conditions of Preschool Educational Institution ... Liudmyla TYMCHUK, et al.

United Nations Organization. (1991). Konwencja o Prawach Dziecka ONZ [The UN Convention on the Rights of the Child]. Retrieved from https://brpd.gov.pl/konwencja-O-prawach-dziecka

Kuc, B., \& Wlazlo, S. (1990). Partnerstwo w sqkole [The psrtnership at school]. Warsaw, Poland: Centrum Doskonalenia Nauczycieli. Oddział.

Kujawiński, J. (1990). Rozwijanie aktywności twórczej uczniów klas poczatkowych: arys metodyki [The development of creative activity of elementary school students]. Warsaw, Poland: WsiP.

Kwiatkowska H. (1997). Edukacja nauczycieli. Konteksty, kategorie, praktyki [Teacher's education. Context, category, practice]. Warsaw, Poland: Inst. Badań Edukacyjnych.

Łobocki, M. (2007). Teoria aychowania w zarysie [The theory of education]. Cracovia, Poland: Impuls.

Maszke, A. (2002). Współpraca i partnerstwo rodziców i nauczycieli [Cooperation of the school with parents]. In A. Karpinska (Ed.), Edukacja w dialogu $i$ reformie. Białystok, Poland: Trans Humana.

Mendel, M. (1998). Rodzice i sžkoła. Jak wspótuczestniczyć w edukacii dzieci? [Parents and teachers. How to cooperatie in the training?]. Torun, Poland: Wyd. Adam Marszałek.

Nowak, S. (1985). Metodologia badań spolecznych [The Modern research methodology]. Warsaw, Poland: Wydawnictwo Naukowe PWN.

Okon, W. (2004). Nowy slownik pedagogiczny [The new pedagogical dictionary]. Warsaw, Poland: Wydawnictwo Akademickie "Zak ".

Pachocinski, R. (2000). Wspolcresne systemy edukacyjne [The modern systems of education]. Warsaw, Poland: IBE.

Pannenkowa, I. (1931). Współpraca domu ze szkoła w Ameryce Pótnocnej [The cooperation of the family and school in America]. Liov - Warsaw, Poland.

Pawlak, B. (2003). Jak współpracowaí z rodzicami uczniów klas poczatkowych? [How to interact with elementary pupils' parents]. Cracocia, Poland: Wydawnictwo Naukowe AP.

Putkiewicz E. (2002, September 14). Idź do szkoly [Go to school]. Dodatek do "Gazety wyborczej》. Retrieved from

https://translate.googleusercontent.com/translate c?depth=1\&hl=ro\&pre $\mathrm{v}=$ search\&rurl=translate.google.com\&sl=pl\&sp $=\mathrm{nmt} 4 \& \mathrm{u}=\mathrm{http}: / /$ www.ar chiwum.wyborcza.pl/Archiwum/1,0,1837945,20020914RP_

DGW D,Idz do szkoly,.html\&xid=17259,15700023,15700186,15700191, $15700256,15700259,15700262,15700265,15700271 \& u s g=A L k J r h g B-7 j 1-$ pJPkzcTN8ii8PUgJAAv A 
Radlińska, H. (1961). Podstawy walki z drugorocznością [Reasons for struggling secondary students]. In H. Radlińska (Ed.), Pedagogika społeczna. Warsaw, poland: Zakład Narodowy im. Ossolińskich.

Radziewicz, J. (1992). Edukacja alternatywna. I innowacjach mikerosystemowych [Alternative education and microsystem innovations]. Warsaw, Poland: WsiP.

Radziwiłł, A. (1975). O wspóldziałaniu między szkeola a domem [The cooperation of the school and family]. Warsaw, Poland: WsiP.

Rościszewska-Woźniak, M. (1998). Organizacja współpracy w przedszkolu [The cooperation in the Preschool]. Edukacja w przedszkolu. Warsaw, Poland: Wydawnictwo RABE.

Ukrainean Parliament. (2005). The law of Ukraine "On preschool education.". Warsaw, Poland: Parliamentary Publishing House.

Trempała, E. (1976). Wychowanie zintegrowane w środowisku szkoly [Integral education in the school environment]. Warsaw, Poland: WsiP.

Ukrainean Parliament. (2016). Ustawa z dnia 14 grudnia 2016 r. - Prawo oświatowe. [The Education Act of 2016, December 14]. Retrieved from http://prawo.sejm.gov.pl/isap.nsf/DocDetails.xsp?id=WDU20170000059

Ukrainean Parliament. (2008). Ustawa z dnia 25 lipca 2008 r. o zmianie ustawy o systemie oświaty, ustawy - Karta Nauczyciela oraz ustawy o postępowaniu w sprawach nieletnich. [The Law on the Status of the Teacher and the Law on Juvenile Delinquency" of 2008, July 25]. Retrieved from http://prawo.sejm.gov.pl/isap.nsf/DocDetails.xsp?id=WDU20081450917

Ukrainean Parliament. (1991). Ustawa z dnia 7 września 1991 r. o systemie oświaty. ["Report on the Status and Directions of Education Development" of 1991, September 7]. Retrieved from https://www.prawo.vulcan.edu.pl/przegdok.asp?qdatprz=akt\&qplikid=1

Wojcik, M. (2014). W poszukiwaniu modelu praktyk nauczycielskich - z doswiadczen i refleksji nauczuciela akademickiego (pedagoga praktyk) [The search for the teaching model- from the expirience of the academic teacher]. Problemy wozesnej edukacji: issuesinearlyeducation, 2(25), 21-45. 